\title{
PROGRAM PENYIAPAN DAN PEMBINAAN GURU BAHASA ARAB PROFESIONAL DI INDONESIA*
}

\author{
Asep M Tamam \\ Universitas Islam Negeri Gunung Djati Bandung \\ email :am.tamam@yahoo.com
}

\begin{abstract}
Professional Arabic teacher preparation program in Indonesia still faces various problems in its regulation and implementation, such as absence of the institution concerned and unavailability of qualified teachers applicant. This article explains how to prepare and develop professional Arabic teachers with integrated programs that will improve the quality of Arabic instruction in Indonesia. Additionally, the competence and professionalism of Indonesian Arabic teachers are increasing in the future.
\end{abstract}

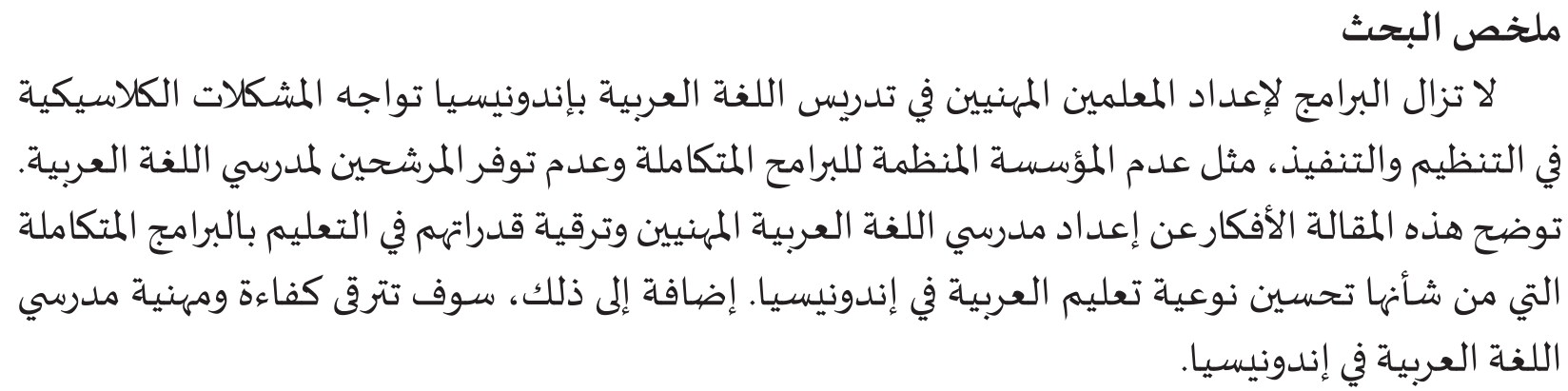

Kata Kunci: guru bahasa Arab, profesional, program penyiapan, pembinaan

\section{Pendahuluan}

Setiap bahasa di dunia memiliki ciri khas unik yang melahirkan watak bahasa, dan watak bahasa menggambarkan alur sejarah serta dimensi budaya yang mengitarinya. Di antara ciri khas unik bahasa Arab adalah keberlimpahan kosa katanya, ketinggian cita rasanya, dan pengaruhnya yang mendalam bagi para penggunanya. Ibnu Khaldun, ${ }^{1}$

1 Nama lengkapnya, Abu Zaid 'Abd alRahman bin Muhammad bin Khaldun al-Khadhrami. Di kalangan pemikir dan ilmuwan Barat, dia sangat dikenal karena pemikirannya dianggap baru dan original. Lahir di Tunisia, 27 Mei 1332/732 H dan wafat 9 Maret 1406/808 H. Dia dianggap sebagai bapak pendiri ilmu historiografi, sosiologi, dan ekonomi. Badri Yatim, Historiografi Islam (Jakarta: Logos Wacana Ilmu, 1997), h. 139-144, atau Azyumardi Azra, Historiografi Islam Kontemporer dalam Muqaddimah'2-nya, menuturkan, "Talenta berbahasa bagi bangsa Arab telah menjadikan bahasa ini memiliki kekuatan dalam berbagai ungkapannya". ${ }^{3}$

(Jakarta: PT SUN, 2003), h. 411, juga en.wikipedia. org/wiki/Ibn_Khaldun.

2 Buku fenomenal karya Ibnu Khaldun. Pengaruh buku ini tidak hanya terjadi di dunia Islam tetapi juga pada peradaban Barat. Orang Yunani menyebut karya Ibnu Khaldun ini sebagai Prolegomena. Sejumlah pemikir sepakat bahwa Muqaddimah adalah karya pertama yang mengkaji filsafat sejarah, ilmu sosial, demografi, historiografi, serta sejarah budaya. Jamil Ahmad, Hundred Great Muslims, terjemahan (Jakarta: Pustaka Firdaus, 2003), h. 504-505 atau Fuad Baali dan Ali Wardi, Ibnu Khaldun dan Pola Pemikiran Islam (Jakarta: Pustaka Firdaus, 2003), h. 23-29, atau lihat: hbis. wordpress.com/200910/24.

Ibnu Khaldun, Muqaddimah (Beirut: Dâr Ihya al-Turats al-'Arabi), h. 547. 
Ungkapan-ungkapan bangsa Arab memiliki otoritas yang kuat dan sulit dicari tandingannya. Muhammad 'Abid al-Jabiri ${ }^{4}$ menyebutkan bahwa otoritas yang ada dalam bahasa Arab tidak hanya mengekspresikan kekuatan bahasa tetapi juga kekuatan bangsa Arab. Mengapa demikian? Sebab, hanya orang Arab yang mampu menguasai bahasa ini dan meninggikannya sampai tingkat ekspresi bayânî yang membedakan mereka dari bangsa yang lain. ${ }^{5}$

Kekuatan yang terkandung dalam bahasa Arab menjadikannya terpilih sebagai bahasa kitab suci terbesar sepanjang sejarah manusia, yaitu al-Qur'an. Kekuatan yang terkandung dalam bahasa al-Qur'an terbukti telah melemahkan bahasa lainnya untuk diterjemahkan ke selain bahasa Arab. Bahasa al-Qur'an tidak seperti bahasa Injil yang berbahasa Siryani yang telah berhasil diterjemahkan ke dalam bahasa Habasyah (Ethiopia) dan bahasa Romawi dengan rasa bahasa yang tidak banyak berbeda. Bahasa Arab telah berhasil menjadi bahasa yang bisa menerjemahkan bahasa Taurat dan Zabur dengan sangat baik. Hal ini karena bangsa-bangsa di luar bangsa Arab tidak memiliki keluasan bahasa yang bisa menampung berbagai ungkapan kehidupan sehari-hari seluas bahasa Arab. ${ }^{6}$ Dengan unsur kekuatan yang dikandungnya, bahasa Arab memiliki akar sejarah yang panjang. Ia menyebar ke seluruh 'pori-pori' bumi

\footnotetext{
4 Lahir di kota Fije, Maroko, tahun 1936. Meraih gelar doktor dari Universitas Rabat, Maroko. Ia adalah intelektual muslim kaliber internasonal dengan gagasan-gagasan kritisnya berkenaan dengan wacana keislaman mutakhir. Lihat: www.uin-Malang.ac.id/index.php.

5 Muhammed 'Abid al-Jâbirî, Takwîn al-'Aql al-'Arabî, terjemahan (Yogyakarta: IECiSoD, 2003), h. 121.

6 Nayif Mahmud Ma'ruf, Khashâ'ish al'Arabiyyah wa Tharâ'iq Tadrîsihâ (Beirut: Dar alNafa'is, 1985), h. 37.
}

seiring dengan perjalanan Islam, agama yang membawanya merembes dari Jazirah Arab ke berbagai negara di luar Arab. ${ }^{7}$

Indonesia merupakan negara yang akrab dan lekat dengan bahasa Arab. Pada abad ke-7 Masehi, bahasa Arab datang di Indonesia bersamaan dengan datangnya agama Islam. $^{8}$ Ajaran Islam mendapat sambutan yang baik dari warga pribumi. Mesjid-mesjid dibangun, lembaga-lembaga pendidikan sederhana didirikan, dan proses Islamisasi digiatkan. Mulailah 7 Bahasa Arab lalu mengalahkan dan menyisihkan bahasa asli wilayah yang didatanginya, sepertiyangterjadidi Mesir,Syam, Yaman,AfrikaUtara, dan lainnya. Namun, sementara Arabisasi berjalan di negara-negara yang didatangi, ada beberapa wilayah atau negara yang masih tetap menggunakan bahasa asli mereka sebagai bahasa keseharian meskipun mereka memilih Islam sebagai agama mereka. Di antaranya adalah bahasa Naubi di selatan Mesir dan Sudan Utara dan Tengah, juga bahasa Kurdi di Irak, bahasa Armania di Syam, bahasa Barbar di Afrika Utara, dan lainnya. Lihat Dardarar Ghafur Hamdamin al-Baliki dalam makalahnya "Ta'lîm al-'Arabiyyah 'alâ al-Mustawâ al-Jâmi'î fî Iqlîm Kurdistân al-Irâq" yang dipresentasikan pada Seminar Internasional Bahasa Arab di Malang Jawa Timur 23-25 November (Malang: Universitas Negeri Malang, 2008), h. 210, atau juga makalah Ishak Rahmani, al-Mâddah alMuqtarahah li Ta'lîm Mukâlamah 'Arabiyah li Thullâb al-Lughah al-'Arabiyyah bi al-Jâmi'ah al-Îrâniyyah yang disampaikan pada seminar internasional bahasa Arab di Universitas Islam al-Azhar (UIA) Jakarta, 22-24 Juli 2010, h. 61.

8 Kedatangan Islam ke Indonesia masih dalam perdebatan, setidaknya ada 3 pendapat kapan pertama kali Islam datang ke Indonesia. Pertama, pendapat sarjana-sarjana orientalis Barat, seperti Snouck Hurgronje, yang mengatakan bahwa Islam masuk di Indonesia pada abad ke-13. Kedua, pendapat sarjana-sarjana Muslim, seperti Hamka, yang menyatakan bahwa Islam masuk ke Indonesia pada abad pertama Hijriyah $( \pm$ abad ke 7 sampai 8 M). Ketiga, sarjana muslim kontemporer, seperti Taufik Abdullah, yang mengkompromikan kedua pendapat tersebut. Taufik menyatakan bahwa Islam betul masuk Indonesia pada abad ke-7 atau 8 masehi, namun secara besar-besaran dan mempunyai kekuatan politik pada abad 13 dengan berdirinya kerajaan Samudra Pasai. Lihat Musyrifah Sunanto, Sejarah Peradaban Islam di Indonesia (Jakarta: Rajawali Pers, 2005) h. 7. 
bahasa Arab diajarkan dan diberikan porsi perhatian yang berangsur terus beranjak. Pada perkembangan selanjutnya, bahasa Arab menempati posisi signifikan karena hubungannya yang erat dengan akidah dan amaliah keagamaan sehari-hari. Akidah dan amaliah keagamaan menjadi faktor utama pengajaran bahasa Arab untuk pertama kali di Indonesia selain beberapa faktor lainnya, seperti perdagangan (ekonomi), sosial, budaya, dan politik. $^{9}$

Pada masa penjajahan Belanda, banyak mahasiswa Indonesia yang melanjutkan studi ke perguruan tinggi di Timur Tengah. Mereka pada umumnya mempelajari bahasa Arab bukan sebagai alat, melainkan sebagai tujuan. Setelah pulang ke tanah air, mereka banyak membawa semangat keilmuan yang tengah melanda negeri-negeri tersebut, tidak saja dalam pendidikan dan pemikiran agama, tapi juga dalam metode pengajaran bahasa Arab. Karena itu, di Padang, Abdulah Ahmad mendirikan madrasah Adabiyah (1909), dua bersaudara Zaenuddin Labay el-Yunusi dan Rahmah Labay el-Yunusiah mendirikan Diniyah Putra (1915) dan Diniyah Putri (1923), dan Ustadz Mahmud Yunus mendirikan sekolah Normal School (1931) yang kemudian dikembangkan di Jawa oleh KH. Imam Zarkasyi di Kulliyatul Mu'allimin al-Islamiyah Gontor Ponorogo. ${ }^{10}$

Langkah-langkah penting dalam penguatan pengajaran bahasa Arab di Indonesia terus berlangsung. Pemerintah terus mengembangkan berbagai hal yang bisa mengakselerasi pemahaman dan penguasaan aneka kemahiran berbahasa

9 'Abd al-Tawwâb 'Abdullah 'Abd al-Tawwâb, I'dâd Mu'allimî al-Lughah al-'Arabiyyah fî al-Jâmi'ah al-Indûnîsiyyah (Jakarta: 'Imadah Syu'ûn al-Ma'âhid fî al-Khârij, 1992), h. 8.

10 Ahmad Fuad Effendi, Metodologi Pengajaran Bahasa Arab (Malang: Misykat, 2004), h. 24 atau Ahmad Izzan, Metodologi Pembelajaran Bahasa Arab (Bandung: Humaniora, 2004), h. 47. bagi putra putrinya. Kementerian Agama dan Departemen Pendidikan terus berupaya mentradisikan pembelajaran bahasa Arab di sekolah-sekolah dan lembaga-lembaga pendidikan lainnya. Berbagai diskusi dan seminar bahasa Arab bertaraf nasional dan internasional tak henti diselenggarakan dalam rangka saling memberi informasi tentang berbagai harapan, tantangan, hambatan, dan kemudian saling memberi masukan tentang solusi pemecahan berbagai masalahnya. Berbagai pelatihan, kursus, dan pendidikan bahasa Arab bagi para guru dan pengajar bahasa Arab pun selalu diadakan bersamaan dengan evaluasi kurikulum dan silabus yang diajarkan.

Namun demikian, hasil dari upaya ini masih belum berhasil, bahkan mendapatkan kendala dan permasalahan krusial. Bukubuku yang mengupas tentang cakrawala kebahasaaraban sering kali menyuguhkan berbagai problematika klasik yang menggelayuti pengajaran bahasa Arab di Indonesia.

Menurut hipotesa penulis, beberapa faktor terpenting dari kegagalan itu adalah banyak lembaga pendidikan di Indonesia yang tidak diimbangi penyediaan tenaga profesional dalam pengajaran bahasa Arab. ${ }^{11}$ Secara umum, di beberapa (banyak) lembaga pendidikan Islam di Indonesia, dari mulai tingkatan SD/MI, SMP/MTs, SMU/Aliyah, hingga perguruan tinggi Islam, para guru bahasa Arab masih didominasi oleh mereka yang bukan

11 Dalam hal ini, Center of Excellence PBA IAIC Institut Agama Islam Cipasung, Tasikmalaya, pernah menyelenggarakan penelitian dengan mengundang lebih dari 200 orang guru pelajaran Bahasa Arab seKabupaten Tasikmalaya Jawa Barat di Aula IAIC, 6 Mei 2008. Ternyata, $80 \%$ lebih dari guru bahasa Arab di MI-MI yang tersebar di Kabupaten Tasikmalaya bukan merupakan alumni dari jurusan Pendidikan Bahasa Arab. Mereka mengajarkan bahasa Arab hanya karena pernah 'mesantren' atau karena kuliah di institut keagamaan, negeri atau swasta. 
alumni dari institusi yang secara khusus mencetak guru bahasa Arab. Demikian satu faktor yang dijelaskan secara menyeluruh dalam buku-buku tersebut di atas. Makalah ini ditulis untuk memberi sumbangan pemikiran tentang betapa pentingnya menyiapkan para guru handal dan profesional dalam pembelajaran bahasa Arab, khususnya di Indonesia.

\section{Misi Guru Bahasa Arab}

Setiap kali diperdengarkan kata "guru", maka spontan ingatan kita terpusat pada mereka yang setiap pagi berangkat ke sekolah dengan seragam yang rapih dan penampilan yang bersahaja. Terpatri pula dalam hati kita berpuluh-ratus sosok yang pernah ataupun sempat mengajari kita berbagai ilmu pengetahuan di dalam ruangan kelas dari mulai tingkat kanakkanak hingga perguruan tinggi. Mereka adalah orang yang paling berjasa bukan hanya pada kita tapi juga bagi negara.

Guru adalah pembangun pertama dan utama peradaban sebuah negara. Mereka adalah sosok utama dalam pengenalan abjad dan alfabet bagi para murid yang membuatnya bisa membaca dan mengerti. Gurulah yang membimbing generasi demi generasi, menuntun dan menemukan berbagai kecenderungan murid-muridnya. Selanjutnya, para murid itu kelak menjadi guru, menjadi ulama, menjadi dokter, profesor, insinyur, seniman, pengusaha, dan lain-lainnya. ${ }^{12}$ Semua ahli sepakat bahwa guru merupakan jantung bagi keberhasilan proses belajar mengajar. Kesuksesan proses pendidikan berada di atas pundaknya. ${ }^{13}$

12 Batsinah al-Khair, al-Lughah al-'Arabiyyah wa al-Ta'lîm (Damaskus: Mathbu'at Majma'al-Lughah al-Arabiyyah, 2000), h. 509.

13 'Abd al-Tawwab 'Abdullah 'Abd al-Tawwab, op. cit., h. 9.
Dalam beberapa dekade terakhir, kita menyaksikan intensitas program pencetakan atau pembinaan guru yang profesional. Di Indonesia, program atau "proyek" sertifikasi mengharuskan para guru meng-up grade kemampuan mereka dengan mengikuti berbagai pelatihan, seminar, workshop, dan lainnya demi akselerasi peningkatan mutu guru dan mutu pembelajaran. Dalam konteks kebahasaaraban, acara-acara yang sama diselenggarakan demi peningkatan mutu guru bahasa Arab, agar tujuan dan sasaran pembelajaran berjalan sesuai dengan harapan.

Misi guru tidak lain adalah membina dan mengembangkan potensi kognitif, afektif, dan psikomotorik murid. Dialah yang mengarahkan murid menuju jalan hidup yang ideal. Pengaruh yang ditanamkan guru pada muridnya bisa jadi mengalahkan pengaruh kedua orangtuanya. Guru pula yang mengarahkan bagaimana hidup bersosialisasi dengan benar kepada muridnya. Dialah yang melatih murid untuk memahami bahkan menguasai keterampilan beretika, berpikir, dan berkreasi. Misi guru ternyata begitu jelas dan agung dalam membina manusia. Karena itu, hakikatnya gurulah sosok yang membina masyarakat dan negara. Tak berlebihan bila dikatakan bahwa guru adalah pembina utama dalam hal ini. ${ }^{14}$

Demikian juga dengan misi guru bahasa Arab. Khusus di Indonesia, gurulah yang menentukan keberhasilan pembelajaran bahasa Arab di Indonesia di samping kurikulum dan silabus yang dirumuskan. Guru mendapat porsi dominan karena bertanggung jawab menyampaikan materi pelajaran agar bisa dimengerti oleh murid. Seloka menyatakan:

\footnotetext{
14 Batsinah al-Khair, loc. cit.
} 
"Guru yang berhasil mampu menyampaikan isi buku/materi ajar, dan yang gagal tidak mampu menyampaikannya."

Mungkin lebih baik jika kita mengetahui bagaimana standar guru yang berhasil. Dalam masalah ini, Batsinah al-Khair menuturkan, "Guru hendaknya cerdas dan tanggap dalam merespons berbagai perubahan dan perkembangan sosial. Hendaknya guru mengerti benar tentang kewajibannya dalam memberikan materi pelajaran yang harus sesuai dengan minatnya. Yang terpenting dimiliki guru adalah perasaan cinta dan sayang terhadap murid-muridnya. Rasa cinta dan sayang ini akan memberikan tanggung jawab untuk membimbing, membina, dan mengarahkan murid-muridnya menjadi generasi yang pandai dan saleh.

Guru hendaknya pula menguasai berbagai materi yang diajarkan kepada muridnya. Ia juga harus memahami perubahan kehidupan dan budaya masyarakat sehingga bisa menjaga muridmuridnya dari budaya negatif yang dominan dalam masyarakat. Lebih jauh dari itu, ia pun dituntut untuk memahami perubahan materi ajar sehingga tidak memokuskan materi pelajaran pada apa yang ada dan terdapat dalam buku ajar. Selanjutnya, ia harus bisa menjaga keseimbangan mental spiritual sehingga lelah dan penat dari berbagai kesibukannya tak berpengaruh terhadap penampilannya dalam mengajar. Terakhir, dia tidak boleh materialis dan pragmatis; maksudnya ikhlas dalam mengajar serta tidak berpikir tentang berapa yang dia peroleh dari acara mengajar dan mendidik." 15

Kecenderungan yang terjadi saat ini, khususnya di Indonesia, memperlihatkan gejala yang bertentangan dengan pendapat

15 Ibid., h. 525.
Batsinah al-Khair tersebut. Meskipun sertifikasi guru dan dosen telah dijalankan, kualitas pembelajaran yang diharapkan masih belum terwujud. Arus pragmatisme bisa jadi mengalir lebih kuat daripada hal serupa ketika wacana sertifikasi belum digulirkan. Tentunya, pemerintah dalam hal ini harus terus megawasi kesuksesan program ini sehingga murid sebagai objek dan subjek pembelajaran memperoleh kepuasan ketika menerima dan mempelajari materi yang disampaikan oleh para guru.

Standar tentang guru ideal yang disampaikan Batsinah al-Khair, bila dihubungkan dengan keberhasilan pengajaran bahasa Arab di Indonesia tentu akan memberikan kontribusi positif dalam mencetak guru-guru bahasa Arab yang mengajar dengan efektif. Maksud mengajar yang efektif adalah pengajaran yang mendapatkan hasil maksimal dengan metode yang sederhana tanpa mengerahkan banyak tenaga dan waktu. ${ }^{16}$

\section{Penyiapan Guru Bahasa Arab Profesional}

Demi menyukseskan pengajaran bahasa Arab di Indonesia, diperlukan rencana dan

16 Muhammad 'Ali al-Khuli, Asâlîb Tadrîs alLughah al-Arabiyyah (Riyad: tp., 1989), h. 31-32. Definisi lain dari Pengajaran Efektif adalah satu sistem aktivitas yang dapat meningkatkan hasil pembelajaran yang dikehendaki dalam suasana yang sehat, demokratis, dan bersemangat. Hasil pembelajaran yang dimaksud adalah perubahan tingkah laku murid akibat penerimaan informasi ilmu atau murid mendapatkan pencerahan baru. Murid pada akhirnya mampu menyeimbangkan perkembangan jasmani, rohani, dan intelektual. Untuk mencapai sebuah pengajaran yang efektif, guru dituntut untuk menguasai materi pelajaran, mengetahui dengan jelas sasaran pengajaran, mengutamakan susunan yang sistematis, banyak menggunakan contoh kehidupan, cakap menggunakan bentuk cerita, menggunakan dan melibatkan pancaindra murid, menggunakan cara mengajar yang hidup, dan menjadikan diri sebagai teladan. 
program yang matang. Upaya mencetak atau mempersiapkan guru bahasa Arab yang handal dan profesional adalah keniscayaan yang tidak bisa ditawar lagi. Untuk menyiapkan guru bahasa Arab yang profesional, kita perlu gambaran yang jelas tentang masyarakat mana yang akan kita persiapkan guru bahasa Arabnya. Setelah itu, kita harus mempelajari kecenderungan dan falsafah hidup serta nilai-nilai yang berlaku di dalam masyarakat tersebut. Konkritnya, tujuan pembelajaran mengacu kepada kebutuhan yang diperlukan pada saat itu oleh masyarakat setempat. ${ }^{17}$

Berbagai penelitian dan studi lapangan telah berhasil mengungkap kelemahan-kelemahan yang berkaitan dengan pengajaran bahasa Arab. Selain itu, penelitian-penelitian itu mengungkap pula kelemahan dan problematika dalam program penyiapan guru bahasa Arab. Program yang lemah tentu akan menghasilkan guru yang lemah. Penyiapan guru bahasa Arab yang lemah pada akhirnya berimbas pada

17 Beranjak dari wacana mengenal masyarakat pengguna bahasa dalam menyusun materi ajar bahasa Arab ini, kita mengenal wacana pembelajaran bahasa berbasis CCU (Cross Culture Understanding). Sejak tahun 1995 atau setelah Muhammad al-Sabt menulis artikel Arabian Business and Cultural Guide, muncul istilah pembelajaran bahasa Arab berbasis Cross Cultural Understanding atau pembelajaran bahasa Arab berbasis pemahaman lintas budaya. Lihat: http://www.kwintessential.co.uk. Gagasan ini muncul sebagai reaksi terhadap fenomena di beberapa masyarakat yang mendalami bahasa lisan bahasa Arab dari materi ajar yang masih berbasis buku-buku karangan orang Arab, sedangkan latar bahasannya adalah masyarakat Timur Tengah. Dalam hal ini, Mudzakir AS memberikan gambaran bagaimana buku ajar bahasa Arab ditulis dengan memperhatikan: (1) aspek isi/materi, (2) aspek penyajian, (3) aspek keterbacaan, (4) aspek grafika, dan (5) aspek keamanan. Lihat makalah Mudzakir AS, "Strategi dan Aplikasi Pemahaman Lintas Budaya dalam Pembelajaran Bahasa Arab", h. 4, yang dipresentasikan pada seminar nasional Pembelajaran Bahasa Arab Berbasis Cross Culture Understanding, FITK UIN Jakarta, 11 Desember 2008. lemahnya kualitas calon guru. Karena itu, kajian lebih lanjut tentang penyiapan guru bahasa Arab yang profesional harus kembali diberi perhatian lebih khusus lagi demi keberhasilan yang lebih memuaskan. ${ }^{18}$

Mengajar adalah profesi yang menuntut berbagai kemampuan dan kemahiran (ability and capability). Kemampuan dan kemahiran tidak hadir dengan sendirinya. Ia dimiliki seseorang kerena sebuah proses pelatihan dan profesionalisasi yang memungkinkannya memahami seluk beluk dan berbagai perangkat kemampuan dalam satu bidang yang ditekuninya.

Ada beberapa istilah dalam masalah ini yang kesemuanya memiliki beda makna tapi satu tujuan. Istilah-istilah itu adalah i'dâd (mempersiapkan), tadrîb (pelatihan), daurah ta'hîliyyah (kursus profesionalisasi). Semua istilah ini memiliki kecenderungan ke arah profesional. Namun, yang biasa dipilih menjadi istilah baku adalah istilah i'dâd. ${ }^{19}$ Istilah ini mengandung makna dan tujuan memberikan kurikulum khusus kepada calon-calon guru bahasa Arab untuk meningkatkan dan mengembangkan kemahiran dan penguasaan ilmu bahasa Arab, juga mengarahkan mereka bagaimana menyampaikan dan mengajarkan materi yang siap diajarkan. Selain itu, para calon guru bahasa Arab juga dibantu dengan berbagai hal yang bisa mengakomodir kebutuhan mereka di lapangan. ${ }^{20}$

Program penyiapan guru profesional harus memiliki prinsip, visi, dan misi. Dalam hal ini, 'Izzat 'Abd al-Maujud

18 Uril Bahruddin, Tathwîr Manhaj Ta'lîm alLughah al-Arabiyyah (Malang: UIN Maulana Malik Ibrahim Press, 2010), h. 11.

19 Untuk selanjutnya, bahasa yang penulis pakai untuk istilah $i^{\prime}$ dâd ini adalah "penyiapan" atau "mencetak" disesuaikan dengan arah pembicaraan dan pembahasan.

20 Yasin 'Abd al-Rahman Qindil, al-Tadrîs wa I'dâd al-Mu'allim (Riyadh: Wizârah al-Nasyr al- Dauli, 1993), h. 182. 
merumuskan beberapa prinsip penyiapan guru bahasa Arab (i'dâd mu'allim al-lughah al-'arabiyyah), yaitu:

1. Menyiapkan (mencetak) para guru bahasa Arab mesti dianggap sebagai sebuah sistem yang utuh dan harus dilakukan dengan serius. Ia bukan program asal-asalan yang mengacuhkan berbagai hal yang berkaitan. Sebaliknya, ia adalah program perencanaan yang menasional sebagai upaya mencetak sumber daya manusia yang handal dan profesional.

2. Program penyiapan tenaga pengajar bahasa Arab harus mencakup tiga aspek, yaitu: aspek budaya, aspek spesialisasi, dan aspek profesi. Ketiga aspek ini harus saling menopang, yang setiap aspeknya saling memberi dan saling bergantung dengan mengacu pada kompetensi maksimal. Kompetensi pengajar bahasa Arab merupakan tujuan tertinggi dari program penyiapan guru bahasa Arab profesional.

3. Program mencetak guru bahasa Arab berbeda dengan program mencetak para peneliti dalam wacana kebahasaaraban. Hal demikian dikarenakan perbedaan tujuan dan peran. Seorang peneliti bahasa melihat bahasa Arab sebagai sebuahfenomenasosial.Seorangpeneliti bahasa Arab memusatkan perhatiannya untuk menganalisis prinsip-prinsip bahasa, lalu menyusun berbagai garis besar yang bisa membantu dan mendukungpemahamanterhadapwatak bahasa dan perkembangannya dalam setiap periodenya. Seorang peneliti juga memusatkan kajian penelitiannya pada berbagai perubahan yang terjadi pada aspek suara, struktur, dan susunan bahasa. Ia juga memokuskan analisisnya pada dialek dan peta bahasa. Kesimpulannya, para peneliti bahasa Arab memusatkan interaksinya pada bahasa dengan menekankan pada wacana bahasa sebagai sebuah kekayaan budaya tutur. Sedangkan, pengajar/ guru bahasa Arab berinteraksi dengan bahasa dan melihatnya sebagai sarana komunikasi untuk mengungkapkan segala keperluan dan berbagai minatnya. Selain itu, guru bahasa Arab melihat bahasa Arab sebagai sarana interaksi antara anggota masyarakat. Ketika guru bahasa Arab mengajarkan bahasa Arab, pada saat yang bersamaan dia mengajarkan proses interaksi dan komunikasi. Yang perlu digarisbawahi di sini, guru bahasa Arab mengajarkan kemahiran berbahasa, yaitu menyimak, berbicara, membaca, dan mengarangsisi lain yang membedakannya dengan penelitibahasaArab.Selain mengajarkan keempat kemahiran di atas, guru bahasa Arab pun mengajarkan bagaimana para murid menyusun pikiran mereka menjadi sebuah kalimat dan bagaimana mengungkapkan pikirannyaitu sehingga cocok dengan suasana dan kondisi yang mengiringinya.

4. Hendaknya setiap institusi, lembaga, atau pesantren yang menyelenggarakan program penyiapan guru bahasa Arab memiliki fasilitas, sarana, dan prasarana yang menunjang keberhasilan program tersebut serta mampu melaksanakan tanggung jawabnya sesuai dengan misi dan tujuan penyelenggaraan program mulia ini.

5. Proses penyiapan guru bahasa Arab memiliki dua tahapan pembinaan. Pertama, menyiapkan mereka menjadi tenaga edukatif (yang memahami dan menguasai materi dan metodologi). Kedua, menyiapkan mereka untuk 
berkhidmah mengamalkan profesinya dan melaksanakan misinya.

6. Peran yang dimainkan guru dalam proses pembelajaran terkadang berubah sesuai dengan perubahan zaman dan juga perubahan teoretis yang melatari pelaksanaannya. Terkadang, peran guru bertambah dan adaptif dengan berbagai perkembangan yang terjadi, ini juga sekaligus mengubah struktur dan materi yang akan diajarkan.

7. Melatih para guru, mengacu pada poin ke-5, ketika mereka berada di tengah misi pengajaran dianggap sebagai strategi yang tepat bagi proses pendidikan yang berkesinambungan. Tak hanya itu, perkembangan profesi guru dianggap pula sebagai hal yang sangat penting bagi guru dan lembaga tempat mengabdi untuk meningkatkan kompetensi guru sekaligus lembaga yang menampungnya. Pendidikan yang berkesinambungan dalam hal ini dianggap sebagai salah satu sarana untuk profesionalisasi pendidikan dalam mewujudkan perkembangan dunia pendidikan. ${ }^{21}$

Prinsip-prinsip penyiapan guru bahasa Arab di atas memberikan gambaran yang utuh di negeri-negeri Timur Tengah. 'Izzat 'Abd al-Maujud mengonfirmasikan tentang keseriusan program mulia ini yang telah berlangsung beberapa lama di negaranegara Arab.

Khusus di Indonesia, program penyiapan guru bahasa Arab profesional telah berjalan lama meskipun belum menampakkan hasil yang menjanjikan. Di satu sisi berhasil tetapi di sisi lainnya terdapat lobang dan celah yang menggambarkan kegagalan. Pesantrenpesantren di Indonesia terus melestarikan

$21 \quad$ Izzat 'Abd al-Maujud, Mu'allim al-Lughah al-'Arabiyyah fî al-Marnalataini al-Ibtidâ'iyyah wa alTsânawiyyah (Khurthum: tp., 1976), h. 359-369. budaya berbahasa Arab ini generasi demi generasi. Metode yang diajarkan tidak seragam dan ini pada gilirannya memberi kendala sekaligus tantangan bagi para pakar dan pemerhati bahasa Arab di tanah air. Pesantren-pesantren tradisional masih utuh dan kukuh mengajarkan bahasa Arab dengan bertitik tumpu pada pengajaran kaidah bahasa (nahw dan sharf). Sementara itu, beberapa pesantren modern menerapkan metode berbeda dalam mengajarkan bahasa Arab bagi para santrinya, yaitu dengan menitikberatkan pada kemahiran bicara dan mengarang (ta'bîr syafahî dan ta'bîr tah rîîî). Perbedaan klasik pembelajaran bahasa Arab di pesantren-pesantren di Indonesia berdampak pada materi dan metode pembelajaran bahasa Arab di sekolah MTs, MA, dan Perguruan Tinggi.

Madrasah Tsanawiyah, Madrasah Aliyah, dan Perguruan Tinggi Islam di Indonesia mendapatkan tantangan untuk meramu metode yang mengakomodir berbagai metode pengajaran di tanah air. Di jurusan Pendidikan Bahasa Arab (PBA), wacana di atas merupakan menu yang terus diramu. Problematikayang menggelayutipengajaran bahasa Arab terus diteliti untuk dicarikan solusinya. Usaha dan upaya maksimal terus dilakukan dan dikembangkan demi memberi pencerahan dalam mempermudah pembelajaran bahasa Arab di tanah air.

Upaya untuk menyukseskan program penyiapangurubahasa Arabyangprofesional terus dilakukan. Program penyiapan guru bahasa Arab, demikian Yasin 'Abd alRahman Qindil, harus memiliki kurikulum atau silabus yang menjawab berbagai dimensi sehingga guru bahasa Arab yang ideal bisa dibina secara berkesinambungan. Berikut ini beberapa sumbangan pemikiran Qindil yang bisa kita pelajari dan kita kaji untuk diadaptasi pada konteks Indonesia: 


\section{Pembekalan Dimensi Kultural}

Bekerja sebagai guru adalah tuntutan untuk menjadi seorang intelektual. Idealnya, seorang guru memiliki pemahaman dan wawasan umum mengenai berbagai bidang ilmu pengetahuan. Program pembekalan dimensi kultural di lembaga-lembaga pencetak kader guru bahasa Arab biasanya berbeda-beda sesuai dengan skala prioritas target yang ingin dicapai. Karena itu, dari satu lembaga ke lembaga lainnya, wacana dimensi kultural ini tidak memililki batasan yang pasti tapi lembaga-lembaga pendidikan umumnya memokuskan objek ilmu-ilmu eksak, di samping juga pemahaman terhadap budaya khas dari rakyat dan masyarakat, juga objek yang berhubungan dengan ilmu-ilmu sosial dan ilmu bahasa. Qindil, dalam hal ini, cenderung memilih wacana pembekalan dimensi kultural dengan kemestian adanya perubahan dari makna tradisional menuju makna modern.

\section{Pembekalan Dimensi Akademis}

Maksud dari pembekalan dimensi akademis adalah kurikulum khas berupa wawasan keilmuan dan kemahiran bagi guru spesialis bidang tertentu yang telah lama dikenal dalam wacana penyiapan guru di lembaga-lembaga penyiapan guru, apakah spesialis ilmu agama, bahasa Arab, ilmu eksak, dan lain-lain. Semua guru yang disiapkan dalam program penyiapan bidang tertentu dituntut untuk mendapat pengetahuan dan wawasan yang cukup dan mumpuni sesuai dengan spesialisasi yang digeluti.

Jumlah dan cakupan kurikulum akademis biasanya berbeda dari satu lembaga dengan lembaga lainnya bergantung pada tingkat dan strata pendidikanyangmelaksanakan program penyiapan guru spesialisasi. Jumlah dan cakupan kurikulum yang disusun dan diajarkan pada materi kimia, misalnya, akan sangat berbeda pada sekolah tingkat SMP dengan materi serupa yang diajarkan pada sekolah SMU.

\section{Pembekalan Dimensi Profesi}

Maksud dari pembekalan dimensi profesi adalah kurikulum yang berusaha memberi pengetahuan seideal mungkin berupa seperangkat pengetahuan dan kemahiran serta pengarahan-pengarahan pedagogis. Seperangkat pengetahuan, kemahiran, dan pengarahan-pengarahan pedagodis ini mesti dikuasai oleh para calon guru yang dibina agar mereka sukses menjalankan prosesi mengajarnya.

Qindil secara terperinci menjelaskan gambaran konkret dimensi ketiga ini dalam ungkapan berikut.

a. Calon guru memahami filsafat pendidikan sesuai dengan undangundang pendidikan yang berlaku di negara yang bersangkutan. Dia juga harus memahami tujuan umum pendidikan di negara tersebut.

b. Calon guru memahami format undangundang dan substansi pendidikan.

c. Calon guru memahami konsep pendidikan internasional dan bisa membandingkannya dengan konsep pendidikan lokal.

d. Calon guru memahami teori-teori psikologi belajar, teori perkembangan anak didik, kesehatan jiwa, serta teori guide and conseling dalam pendidikan dan teori-teori yang bisa membantunya dalam melakukan tugasnya. 
e. Calon guru memahami cara menyusun kalender dan metodologi akademis.

f. Calon guru memahami berbagai metode, prinsip, dan sarana pembelajaran.

g. Calon guru mampu melakukan praktik kerja dan praktik lapangan, yaitu mentransfer pengetahuan yang ditunjukkan (oleh poin a-f di atas) dalam sebuah konsep yang bisa menuntun sikap dan praktik guru di kelas.

Qindil memprosentasikan pembekalan dimensi profesi ini sebanyak $25 \%-35 \%$ dari faktor keberhasilan penyiapan guru profesional bahasa Arab. Hal ini bila dibandingkan dengan dimensi pertama dan kedua di atas yang memiliki persentase keberhasilan $65 \%$ sampai $75 \% .{ }^{22}$

\section{Kualifikasi Guru Bahasa Arab Profesional}

Program penyiapan atau pencetakan guru bahasa Arab yang sukses haruslah memiliki standar kemampuan yang jelas. Standarisasi guru bahasa Arab yang profesional dimaksudkan untuk mendapatkan hasil maksimal dari program yang serius dicanangkan dari awal, tengah, hingga di akhir pelaksanaannya. Untuk mencapai target yang maksimal, sejak awal harus dirumuskan daftar kualifikasi kemampuan dan kemahiran berbahasa atau kemampuan terhadap tiga unsur dimensi pelatihan dan pembinaan pembekalan yang tersebut dalam pembahasan sebelumnya.

Berikut ini daftar kualifikasi kemampuan dan kemahiran calon guru bahasa Arab setelah digembleng dalam pembinaan dan pembakalan. Daftar kualifikasi ini dirumuskan oleh 'Ali Muhammad alQasimi:

22 Yasin 'Abd al-Rahman Qindil, op. cit., h. 184186.

\section{Kemampuan Memahami Bahasa Oral}

- Standar minimal: calon guru mampu memahami apa yang diucapkan tokoh luar negeri (penutur bahasa Arab) ketika dia berbincang dan mengatakan sesuatu secara sederhana tantang satu tema.

- Standar baik: calon guru mampu memahami satu pembicaraan yang berlangsungsecarasemicepat.Demikian juga ia bisa memahami ceramah yang disampaikan di hadapannya. Ia juga mampu memahami iklan yang disiarkan secara oral.

- Standar excellence (mahir): calon guru mampu memahami secara sempurna segala macam pembicaraan yang dilakukan dengan intonasi jelas tanpa kesulitan, apakah pembicaraan yang diikutinya itu cepat, atau dilakukan oleh orang banyak, atau ketika menyaksikan film atau sandiwara.

- Evaluasi: ujian bagi calon guru memungkinkan dilakukan dengan imlâ (dikte) ataupun dengan ujian untuk mengetahui seberapa baik dia menyerap soal yang diajukan panitia penerimaan masuk perguruan tinggi yang fokus mengadakan ujian semacam ini.

\section{Kemampuan Berbicara}

- Standar minimal: calon guru mampu berbicara tentang suatu tema yang terlebih dahulu disiapkan padanya. Ia berbicara tentang tema itu dengan jelas tanpa ragu dan tanpa terbata-bata. Demikian juga ia mampu menggunakan ungkapan-ungkapan yang populer dan menyesuaikan diri dengan konteks negara-negara luar negeri. Ia mengemukakan ungkapannya itu dengan jelassehingga mudah dimengerti oleh para pendengarnya. 
- Standar baik: calon guru mampu berbicara dengan orang luar negeri tanpa terjadi kesalahan yang parah. Ia juga mampu menempatkan mufradât (kosakata) dan susunan kalimat serta mampu mengungkapkan gagasangagasan dalam pembicaraan yang panjang lebar. Dalam hal ini, termasuk berbicara dengan cepat dengan notasi dan susunan yang baik.

- Standar excellence (mahir): calon guru mampu menyamai pembicaraan orang luar negeri dengan mufradat, nada dan notasinya. Contohnya seperti berdiskusi dan curhat (mencurahkan ungkapan hati) dengan lancar tanpa kendala.

\section{Kemampuan Membaca}

- Standar minimal: calon guru mampu memahami teks bacaan biasa (prosa) yang mudah dan bukan bacaan yang berhubungan dengan teknik (tema tertentu). Pemahaman yang dikuasainya mesti bersifat langsung tanpa perantaraan terjemah kecuali dalam situasi terdesak.

- Standar baik: calon guru mampu membaca teks bacaan biasa (prosa) atau teks syair (puisi) yang cukup sulit dan mengandung tema yang cukup serius. Dia memahaminya secara langsung seolah-olah dia tengah membaca teks dengan bahasanya sendiri/bahasa ibu (lughah umm).

- Standar excellence (mahir): calon guru mampu membaca materi yang benar-benar sulit seperti makalah atau teks kritik sastra. Bacaannya mesti dilakukan dengan mudah sebagaimana dia membaca teks yang berbahasa ibu.

- Evaluasi:memungkinkanujiandilakukan dengan mengajukan beberapa teks yang disusun rapi dengan beberapa tema.
Susunannya disesuaikan dengan tingkat kesulitan yang disediakan untuk jangka waktu tertentu. Teks soal ini dilengkapi dengan beberapa pertanyaan untuk mengetahui penguasaannya dalam berbagai wacana. Evaluasi dilakukan dengan memberikan beberapa soal multiple choice atau essay.

\section{Kemampuan Menulis}

- Standar minimal: calon guru mampu menulis dengan format yang benar ungkapan-ungkapan dan paragrafparagraf yang memungkinkan diungkapkan secara lisan di depan kelas. Demikian juga, ia mampu menulis sebuah surat yang pendek.

- Standarbaik: calonguru mampumenulis karangan bebas yang sederhana dan jelas dengan dibumbui mufradat dan idiom yang fasih. Kaidah-kaidah nahwu dan sharf dalam hal ini diterapkan dengan benar.

- Standar excellence (mahir): calon guru mampu menulis berbagai tema dengan alami, diungkapkan dengan mudah, dan uslûb-nya benar-benar terasa.

- Evaluasi: evaluasi mungkin dilakukan dengan mengajukan beberapa susunan bahasa, lalu calon guru yang diuji ini memilih susunan yang benar. Demikian juga bisa dengan mengimla (dikte) dan menerjemahkan ungkapan-ungkapan bahkan paragraf-paragraf dari bahasa ibu (bahasa nasional) ke dalam bahasa luar. Evaluasi juga bisa dilakukan dengan menulis surat yang memiliki tema tertentu atau menulis karangan bebas.

\section{Kemampuan Menganalisa Bahasa}

- Standar minimal: calon guru memahami formasi suara (fonem) dan tata bahasa 
(grammar) bahasa asing. Calon guru juga harus mengetahui perbedaanperbedaan prinsip antara bahasa asing dengan bahasa nasional muridmuridnya.

- Standar baik: secara mendasar, calon guru memahami perkembangan sejarah dan karakteristik terbaru dari bahasa asing. Dia juga mengetahui perbedaanperbedaan di antara bahasa lisan dengan bahasa tulisan dari bahasa asing yang dipelajarinya.

- Standar excellence: calon guru mengetahui bagaimana menerapkan kemampuanya tentang ilmu bahasa deskriptif, kontrastif, dan historik dalam kesempatan mengajar bahasa asing yang dipelajarinya.

- Evaluasi: pengetahuan dan kemampuan calon guru dalam item ini bisa dievaluasi sesuai dengan strata pendidikan. Untuk pemula, bisa diajukan pertanyaanpertanyaan multiple-choice bebas tentang pola-pola pengucapan dan intonasi bahasa asing disertai pertanyaan tentang kaidah-kaidah bahasa (grammar). Untuk strata intermediate dan advance, evaluasi bisa dilakukan dengan mengajukan pertanyaan seputar fiqh lughah dan ilmu lughah.

\section{Kemampuan Mengenal Budaya}

- Standar diterima (minimal): calon guru mengetahui bahwa bahasa adalah unsur penting dalam semua unsur yang menciptakan budaya bagi sebuah bangsa. Calon guru juga harus mengetahui dimensi geografi, sejarah, peradaban, kesenian, tradisi yang melekat pada kehidupan sosial dan perkembangan kehidupan modern dari suatu bangsa.
- Standar baik: calon guru mengetahui secara langsung (lapangan) tentang keindahan budaya suatu bangsa. Ia juga mengetahui dari kebudayaan itu mana yang sesuai dan tidak sesuai dengan budaya murid-muridnya. Di samping itu, ia juga mengetahui informasi-informasi yang benar tentang bangsa lain dan modernitas yang berlangsung di bangsa itu.

- Standar excellence: calon guru mengetahui secara mendalam tentang budaya bangsa lain yang diminatinya. Informasi yang ia dapatkan adalah hasil dari komunikasi intensif dengan penduduk bangsa yang diminatinya. Lebih baik lagi, calon guru mengetahui informasi bangsa yang dipelajarinya itu dengan cara mengadakan perjalanan langsung dan bermukim di negara itu, lalu mempelajari dan meneliti secara konseptual tentang peradaban dan budaya bangsa itu.

- Evaluasi: calon guru mampu menganalogikan pengetahuannya dengan ujian yang ruang lingkupnya tentang budaya dan peradaban dengan pertanyaan-pertanyaan dalam bentuk multiple choice bagi strata pemula (beginner) dan intermediate. Bagi calon guru pada strata advance, ia diuji dengan diminta komentarnya secara tertulis dalam bentuk prosa atau puisi. Isi dari komentarnya adalah diskusi yang menyingkap berbagai sisi penting dari budaya negara asing .

\section{Kemampuan dan Pengetahuan Profesionalitas Guru}

- Standar diterima (minimal): calon guru mengetahui metode-metode dan teknikteknik yang efektif dalam pengajaran bahasa Arab. 
- Standar baik: calon guru mampu menerapkan pengetahuannya tentang metode dan teknik mengajarnya itu dalam praktik mengajar. Ia juga bisa meramu berbagai metode dan teknik mengajar bahasa dengan metode lainnya dalam kesempatan mengajarnya.

- Standar excellence (mahir): calon guru mampu mempraktikkan berbagai metode pengajaran bahasa yang selama ini diakui dalam konteks pengajaran bahasa. Ia juga mampu mengadaptasikan pengalamannya dengan metode-metode dan teknikteknik terbaru serta siap mempraktikkannya bila dibutuhkan. ${ }^{23}$

\section{Simpulan}

Upaya untuk membumikan bahasa Arab di Indonesia adalah upaya mulia yang tak akan lekang dihempas zaman. Pengajaran dan pembelajaran yang ideal tentunya menjadi satu di antara berbagai pintu yang bisa membuka jalan ke arah upaya itu. Menyiapkan para guru profesional menjadi bagian penting dalam mewujudkan pengajaran dan pembelajaran efektif demi mengurai benang kusut pembelajaran bahasa Arab di Indonesia. Membekali calon guru bahasa Arab dengan berbagai pengetahuan; teori atau substansi, retorika atau eksekusi, sejatinya diselenggarakan dalam program terpadu dan berkesinambungan dengan tajuk I'dâd Mu'allim al-Lughah al-'Arabiyyah.

Lembaga-lembaga dan perguruanperguruan tinggi Islam yang membina calon guru bahasa Arab telah menyejarah dalam perjalanan bahasa Arab di tanah air. Namun,

23 'Ali Muhammad al-Qasimi, Ittijâhât Hadîtsah fî Ta'lîm al-'Arabiyyah li al-Nâthiqîn bi al-Lughah alUkhrâ (Riyadh: 'Imadah Syu'un al-Maktabah Jami'ah Riyadh, 1979), h. 359-369. program ini, meskipun telah menelorkan para guru bahasa Arab, belum memberikan solusi bagi beragam problem yang menggelayuti wacana kebahasaaraban di Indonesia. Dengan program profesionalisasi yang ditunjang kurikulum yang baik dan menyentuh kebutuhan riil masyarakat bahasa Arab di Indonesia, diharapkan guru-guru bahasa Arab mampu memiliki pengetahuan yang mumpuni dalam bidang pembelajaran bahasa Arab serta dapat menyebarkan syiar bahasa Arab di mana pun mereka berada.

Pandangan 'Izzat 'Abd al-Maujud yang merekomendasikan agar program penyiapan guru mencakup tiga aspek utama: budaya, spesialisasi, dan profesi, hendaknya dipertimbangkan. Begitu pula pandangan Qindil yang menyatakan bahwa faktor keberhasilan penyiapan guru profesional bahasa Arab ditopang oleh pembekalan dimensi profesi sekira $25 \%-35 \%$, serta dimensi kultural dan akademis sekira $65 \%$ sampai $75 \%$. Karena itu, dalam pelaksanaannya, kita perlu memperhatikan daftar tujuh kualifikasi kemampuan dan kemahiran calon guru bahasa Arab dari 'Ali Muhammad alQasimi, yaitu kemampuan memahami bahasa oral, berbicara, membaca, menulis, menganalisa bahasa, mengenal budaya, dan profesionalitas keguruan. [] 


\section{Daftar Rujukan}

'Abd al-Maujud, 'Izzat, Mu'allim al-Lughah al-'Arabiyyah fî al-Marhalataini al-Ibtidâ'iyyah wa alTsânawiyyah, Khurthum: tp., 1976.

'Abd al-Tawwab, 'Abdullah 'Abd al-Tawwab, I'dâd Mu'allimî al-Lughah al-'Arabiyyah fî al-Jâmi'ah alIndûnîsiyyah, Jakarta: 'Imadah Syu'un al-Ma'ahid fi al-Kharij, 1992.

Ahmad, Jamil, Hundred Great Muslims, terjemahan, Jakarta: Pustaka Firdaus, 2003.

Azra, Azyumardi, Historiografi Islam Kontemporer, Jakarta: PT SUN, 2003.

Baali, Fuad dan Ali Wardi, Ibnu Khaldun dan Pola Pemikiran Islam, Jakarta: Pustaka Firdaus, 2003.

Bahruddin, Uril, Tathwîr Manhaj Ta'lîm al-Lughah al-'Arabiyyah, Malang: UIN Maulana Malik Ibrahim Press, 2010.

al-Baliki, Dardarar Ghafur Hamdamin, makalah, "Ta'lîm al-'Arabiyyah 'alâ al-Mustawâ al-Jâmi îfî̀ Iqlîm Kurdistân al-'Irâq, Malang: Universitas Negeri Malang, 2008.

Effendi, Ahmad Fuad, Metodologi Pengajaran Bahasa Arab, Malang: Misykat, 2004.

en.wikipedia.org/wiki/Ibn_Khaldun, diakses tanggal: 12-02-2014

http://www.kwintessential.co.uk, diakses tanggal: 5-03-2014

Izzan, Ahmad, Metodologi Pembelajaran Bahasa Arab, Bandung: Humaniora, 2004.

al-Jabiri, Muhammad 'Abid, Takwîn al-'Aql al-'Arabî, terjemahan, Yogyakarta: IECiSoD, 2003.

al-Khair, Batsinah, al-Lughah al-'Arabiyyah wa al-Ta'lîm, Damaskus: Mathbu'ah Majma' al-Lughah al'Arabiyyah, 2000.

Khaldun, Ibnu, Muqaddimah, Beirut: Dar Ihya al-Turats al-'Arabi, tt.

al-Khuli, Muhammad 'Ali, Asâlîb Tadrîs al-Lughah al-'Arabiyyah, Riyadh: tp., 1989.

Ma'ruf, Nayif Mahmud, Khashâ'ish al-'Arabiyyah wa Tharâ'iq Tadrîsihâ, Beirut: Dar al-Nafa'is, 1985.

Mudzakir AS, "Strategi dan Aplikasi Pemahaman Lintas Budaya dalam Pembelajaran Bahasa Arab", makalah pada seminar nasional Pembelajaran Bahasa Arab Berbasis Cross Culture Understanding, FITK UIN Jakarta, 11 Desember 2008.

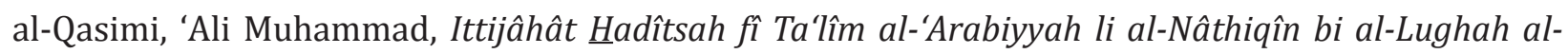
Ukhrâ, Riyadh: 'Imadah Syu'un al-Maktabah Jami'ah Riyadh, 1979.

Qindil, Yasin 'Abd al-Rahman, al-Tadrîs wa I'dâd al-Mu'allim, Riyadh: Wizarah al-Nasyr al-Dauli, 1993.

Rahmani, Ishak, "al-Mâddah al-Muqtarahahah li Ta'lîm Mukâlamah 'Arabiyyah li Thullâb al-Lughah al'Arabiyyah bi al-Jâmi'ah al-Îrâniyyah", makalah, disampaikan pada Seminar Internasional Bahasa Arab di Universitas Islam al-Azhar (UIA) Jakarta, 22-24 Juli 2010.

Sunanto, Musyrifah, Sejarah Peradaban Islam di Indonesia, Jakarta: Rajawali Press, 2005.

Yatim, Badri, Historiografi Islam, Jakarta: Logos Wacana Ilmu, 1997.

www.uin-Malang.ac.id/index.php, diakses tanggal: 5-03-2013 